\title{
Herbal Compounds in the Treatment of Pulmonary Silicosis
}

\author{
Jana ADAMCAKOVA ${ }^{1}$, Daniela MOKRA ${ }^{1}$ \\ ${ }^{1}$ Department of Physiology, Jessenius Faculty of Medicine in Martin, Comenius University in \\ Bratislava, Martin, Slovak Republic
}

Received April 16, 2021

Accepted October 11, 2021

\section{Summary}

Herbal compounds including those already well-established in traditional Chinese medicine have been increasingly tested in the treatment of various diseases. Recent studies have shown that herbal compounds can be of benefit also for pulmonary silicosis as they can diminish changes associated with silica-induced inflammation, fibrosis, and oxidative stress. Due to a lack of effective therapeutic strategies, development of novel approaches which may be introduced particularly in the early stage of the disease, is urgently needed. This review summarizes positive effects of several alternative plant-based drugs in the models of experimental silicosis with a potential for subsequent clinical investigation and use in future.

\section{Key words}

Pulmonary silicosis • Inflammation • Fibrosis • Anti-inflammatory treatment $\bullet$ Herbal treatment

\section{Corresponding author}

D. Mokra, Department of Physiology, Jessenius Faculty of Medicine in Martin, Comenius University in Bratislava, Mala Hora 4C, SK-03601 Martin, Slovak Republic. E-mail: daniela.mokra@uniba.sk

\section{Introduction}

Herbal compounds have ben already wellestablished in traditional Chinese medicine for treatment of various diseases. Several of plant-based medicines have been successfully used as an adjunctive treatment in many respiratory disorders including inflammatory lung diseases, bronchial asthma, chronic obstructive pulmonary disease, cough or COVID-19 (Wagner et al. 2015, Santana et al. 2016, Shergis et al. 2016, Ang et al.
2020, Yang and Yang 2021).

Recent studies have shown that herbal compounds can be of benefit also for pulmonary silicosis (Li et al. 2017a, Peng et al. 2017, Liu et al. 2019, Zhu et al. 2020, Li et al. 2021a). Pulmonary silicosis is a serious fibrotizing disease caused by prolonged and/or long-term inhalation of silica particles. The changes accompanied with silica inhalation, such as accumulation of lymphocytes and alveolar macrophages in the interstitium, thickening of the pulmonary interstitium mass, formation of hyalinized fibrotic nodules, and deposition of collagen fibres, are strongly associated with silica-induced inflammation and oxidative stress. Because of complex pathophysiology of the disease, persistence of silica particles in the lung, and perpetuation of proinflammatory and pro-fibrotic cascades, development of novel approaches targeting inflammation and fibrosis particularly in the early stages of the disease is urgently needed. This article provides a short review of pathophysiology of pulmonary silicosis as a rationale for recommended therapy and summarizes the positive effects of several alternative plant-based drugs in the models of experimental silicosis with a potential for subsequent clinical investigation and use in future.

\section{Pulmonary silicosis}

Intensive and/or long-term exposure to inhaled silica results into a complex and still not fully understood activation of several pathomechanisms (Hamilton et al. 2008, Harijith et al. 2014, Sayan and Mossman 2016). For better understanding the rationale of the treatment, a short overview of the pathomechanisms and their 
interactions is provided in the subsection below, while more details may be found in our recent article (Adamcakova and Mokra 2021).

Inhaled silica crystals are extremely toxic to the lung tissue. Due to their piezoelectric properties, they directly trigger a generation of reactive oxygen species (ROS) (Hamilton et al. 2008). Silica particles are rapidly recognized by receptors on the surface of alveolar macrophages, or airway epithelial cells, and subsequently engulfed by these cells (Øvrevik et al. 2006, Hamilton et al. 2008). However, the internalized silica cannot be broken by lysosomal enzymes what leads to damage of lysosomal membrane integrity and silica freed from destroyed macrophages can be internalized by other macrophages generating a vicious cycle of silica toxicity to alveolar macrophages (Hamilton et al. 2008). Released lysosomal enzymes including protease cathepsin B, ROS overproduction, activation of the surface receptors with activation of the related pro-inflammatory pathways, e.g. nuclear factor (NF)- $\kappa \mathrm{B}$ and mitogen-activated protein kinase (MAPK), $\mathrm{K}^{+}$efflux, extracellular adenosine triphosphate (ATP) etc. subsequently stimulate an activation of nucleotide-binding and oligomerization domain-like receptor (NLR)P3 inflammasome, a special intracellular receptor complex (Tschopp and Schroder 2010, Sayan and Mossman 2016). Activation of NLRP3 inflammasome triggers an activation of caspase-1 which induces a pyroptosis, a highly pro-inflammatory type of cell death, which is linked with a release of interleukin (IL)-1 $\alpha$, IL-1 $\beta$, IL-18, high mobility group box 1 protein (HMGB1), ROS etc. (Bergsbaken et al. 2009). These mediators trigger an expression of other pro-inflammatory cytokines including tumor necrosis factor (TNF) $\alpha$ which increase the influx of neutrophils into the lung and damage the epithelial cells. The mentioned bioactive substances, particularly IL-1 $\beta$, enhance a recruitment of fibroblasts and a production of pro-fibrotic transforming growth factor (TGF)- $\beta$. TGF- $\beta$ induces activation, proliferation, and transdifferentiation of epithelial cells and fibroblasts into myofibroblasts generating components of extracellular matrix, e.g. collagen. High concentrations of pro-fibrotic substances and recruitment of collagen- and fibronectin-producing cells predispose to formation of silicotic nodules, scaring the lung tissue and reduction of areas providing a gas exchange (dos Santos et al. 2012, Pardali et al. 2017).

Excessive concentrations of produced ROS cause mitochondrial dysfunction, forcing alveolar macrophages to undergo a mitochondrial apoptosis.
However, in this form of cell death, alveolar macrophages release cell organelles and high amounts of bioactive substances and ROS further injuring the lung tissue. To prevent a potential injury, autophagy as a special form of cell elimination sequesters dysfunctional and potentially toxic macromolecules and injured organelles into double-membrane autophagosomes (Kim and Lee 2014) and damaged mitochondria may be eliminated by mitochondria-selective autophagy (or mitophagy) (Palikaras et al. 2018). Reducing production of ROS, autophagy and mitophagy prevent the excessive secretion of pro-inflammatory factors and eventual progression of fibrosis induced by silica.

\section{Treatment of pulmonary silicosis}

Because of no causal pharmacological treatment of silicosis, patients are treated only symptomatically using bronchodilators and antitusic and mucolytic agents (Barnes et al. 2019). Important is also prevention of the additional exposures to silica and curing the respiratory infections (Cullinan and Reid 2013). In several trials, a whole lung lavage was used in acute silicoproteinosis to decrease a presence of dust particles and inflammatory cells in the bronchoalveolar lavage fluid (BALF) (Zhang et al. 2012) but this approach had no effect on long-term outcome or mortality or even increased a risk of complications (Stafford et al. 2013). As a last resort after exhaustion of other therapeutic options, lung transplantation may be indicated. However, long-term survival after lung transplantation has a poor prognosis (Lopes-Pacheco et al. 2016).

Several novel experimental approaches are based on suppression of activation of inflammasome, e.g. by reduction of oxidative stress by antioxidants, restoring the function of autophagy-lysosomal system, or by blocking pro-inflammatory cytokines or pro-fibrotic factors (Harijith et al. 2014, Lee et al. 2014, Song et al. 2014, Sugimoto et al. 2019, Zahid et al. 2019, Caseley et al. 2020). Favorable results have been also published for treatment with microRNA (Das et al. 2014, Xu et al. 2019, Qi et al. 2020), mesenchymal stem cells (Liu et al. 2015a, Chen et al. 2018, Li et al. 2018) or extracellular vesicles from mesenchymal stem cells (Choi et al. 2014, Phinney et al. 2015, Bandeira et al. 2018). Some improvement for lung fibrosis including silicosis can be also found for agents increasing cyclic adenosine monophosphate (cAMP) or guanosine monophosphate (cGMP), e.g. inhibitors of phosphodiesterases (Rabolli 
et al. 2011, Abdelaziz et al. 2016, Fehrholz et al. 2017, Sisson et al. 2018, Kolb et al. 2018, Wu et al. 2020), or for corticosteroids (Barbarin et al. 2005, Trentin et al. 2015, Ferreira et al. 2020).

\section{Treatment with herbal compounds}

In addition to the previously mentioned approaches, there is an increasing number of experimental studies demonstrating a wide potential of herbal drugs in the treatment of lung silicosis. Some of these plant-based compounds can influence one or even several of the pathomechanisms of silicosis and thereby they can mitigate the silica-induced inflammation and/or fibrosis.

In the following part of this article, effects of the most promising phytomedicines are discussed. Dosages and modes of delivery are listed in Table 1, natural sources and chemical structure of the compounds are provided in Figure 1.

Table 1. Dosages and modes of delivery of herbal treatments in experimental models of silicosis.

\begin{tabular}{lcccc}
\hline Compound & $\begin{array}{c}\text { Model of } \\
\text { silicosis }\end{array}$ & $\begin{array}{c}\text { Mode of } \\
\text { delivery }\end{array}$ & Daily dose & References \\
\hline $\begin{array}{l}\text { Sodium tanshinone IIA } \\
\text { sulfonate }\end{array}$ & Rat & i.p. & $25 \mathrm{mg} / \mathrm{kg}$ & Zhu et al. 2020 \\
$\begin{array}{l}\text { Kaempferol } \\
\text { Astragaloside IV }\end{array}$ & Mouse & i.p. & $150 \mathrm{mg} / \mathrm{kg}$ & Liu et al. 2019 \\
Dioscin & Rat & i.p. & $20 \mathrm{mg} / \mathrm{kg}$ & Li et al. 2019 \\
Oleanolic acid & Mouse & p.o. & $80,40, \mathrm{or} 20 \mathrm{mg}$ & Du et al. 2019, \\
Hesperetin & Rat & i.g. & $60 \mathrm{mg} / \mathrm{kg}$ & Peng et al. $2017 \mathrm{a}$ \\
Emodin & Rat & i.g. & $100,200, \mathrm{or}$ & Li et al. 2021 \\
\hline
\end{tabular}

Abbreviations: i.p.: intraperitoneally, p.o.: orally, i.g.: intragastrically.

\section{Sodium tanshinone IIA sulfonate}

Sodium tanshinone IIA sulfonate (STS) is a hydrosoluble extract of Salvia miltiorrhiza which is used in traditional Chinese medicine for the treatment of coronary heart disease. Moreover, STS has shown its potent antioxidant, anti-inflammatory, and anti-apoptotic actions in various diseases through regulating various transcription factors including $\mathrm{NF}-\kappa \mathrm{B}$ and through influencing $\mathrm{Ca}^{2+}, \mathrm{K}^{+}$and $\mathrm{Cl}^{-}$ion channels (Zhou et al. 2019, Zhu et al. 2020).

In a rat model of silicosis, intraperitoneal injection of STS significantly reduced collagen deposition in the lung and reduced ROS as demonstrated by a decrease in production of malondialdehyde (MDA), a marker of lipid peroxidation in oxidative stress. Authors presume that the anti-fibrotic effects of STS may be related to upregulation of nuclear factor erythroid 2-related factor 2 (Nrf2) expression and nuclear translocation and the subsequent increase in transcription of thioredoxin and its reductase (Zhu et al. 2020). Antioxidant and anti-fibrotic effects of STS were previously demonstrated in bleomycin-induced pulmonary fibrosis where STS reduced a production of lipid peroxides and hydroxyproline (Wang et al. 1994) as well as in in vitro model of lipopolysaccharide-induced pulmonary fibrosis where STS downregulated the protein expressions of IL-1 $\beta$ and TNF $\alpha$, and inhibited TGF- $\beta 1$-induced cell proliferation and overexpression of $\alpha$-smooth muscle actin (SMA) and collagen-1 (Jiang et al. 2020). Promising results have been also demonstrated in other types of the lung injury. For instance, in a rat model of seawater-aspiration and in isolated alveolar type II cells, STS attenuated a generation of pulmonary edema enhancing the activity of $\mathrm{K}^{+}$-ATPase, $\mathrm{Na}^{+}$and extracellular signal-regulated kinases (ERK)1/2 (Xie et al. 2011). In a rabbit model of endotoxemia, STS pretreatment reduced injury to the lung, heart, and liver (Ma et al. 2018). 


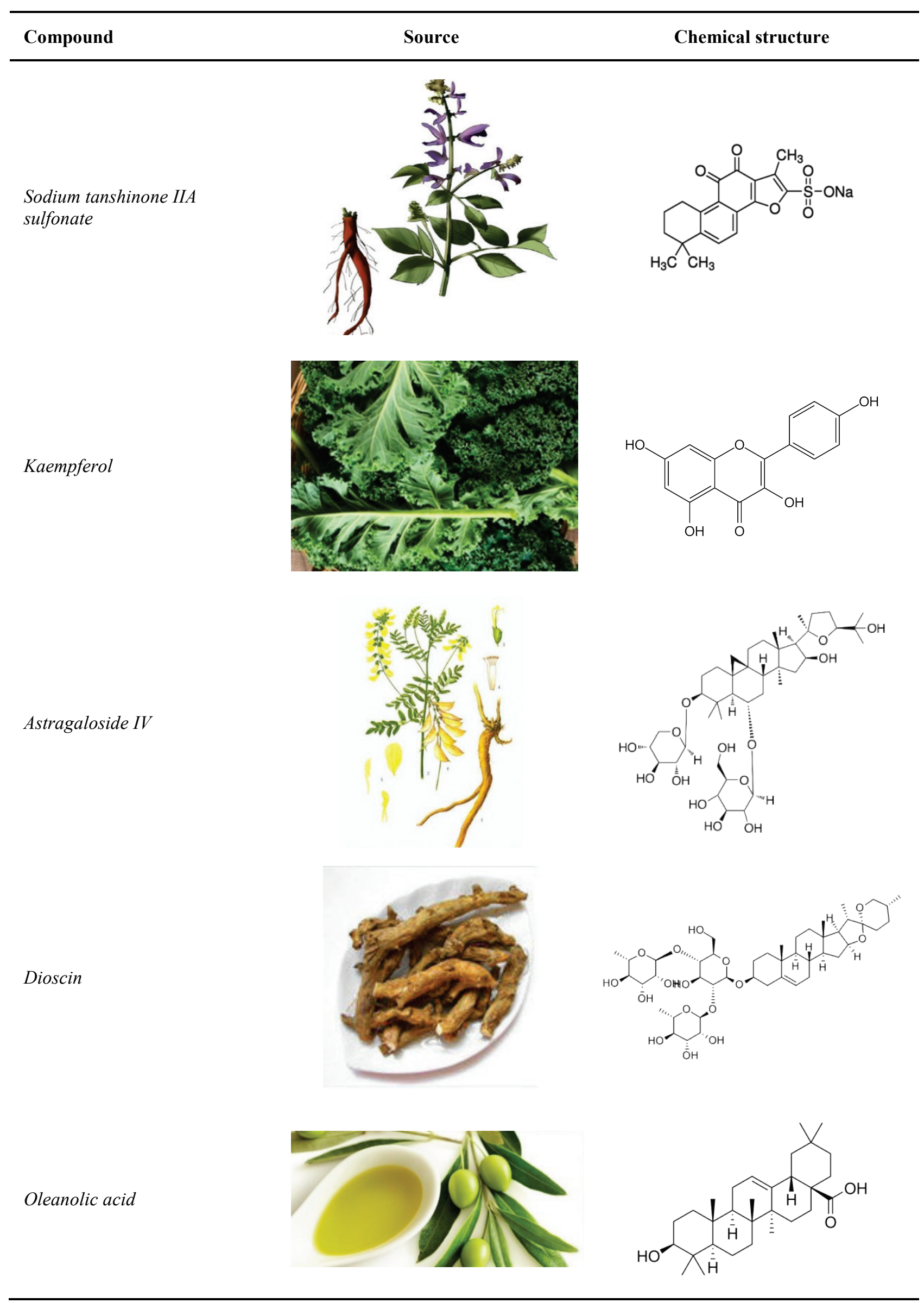


Hesperetin

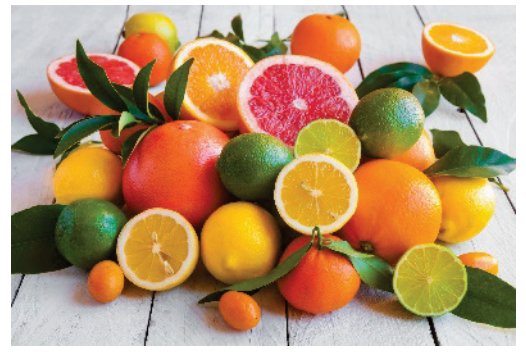<smiles>COc1ccc(C2CC(=O)c3c(O)cc(O)cc3O2)cc1O</smiles>

Emodin

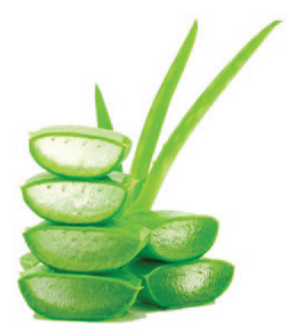<smiles>Cc1cc(O)c2c(c1)C(=O)c1cc(O)cc(O)c1C2=O</smiles>

Fig. 1. Herbal compounds used in the experimental treatment of pulmonary silicosis.

\section{Kaempferol}

Kaempferol (Kae) is a flavonoid widely present in many plants, fruits and vegetable (Amaral-Machado et al. 2020). Kae exerts wide anti-inflammatory, antioxidative and anti-fibrotic effects including inhibition of TLR4 receptor, NF- $\mathrm{B}$ and MAPK pathways, suppression of the release of IL-6, IL-1 $\beta$, IL-18 and TNF $\alpha$, attenuation of oxidative stress via activation of Nrf2-ARE signaling pathway etc. (Alam et al. 2020, Amaral-Machado et al. 2020).

In a murine model of silicosis, intraperitoneally administrated Kae modulated silica-induced autophagy and significantly inhibited pulmonary inflammation at day 7 what was demonstrated by lower expressions of pro-inflammatory cytokines, and inhibited silica-induced pulmonary fibrosis at day 28 what was demonstrated by suppressed activation of matrix metalloproteinase- 2 and smaller silicotic nodules (Liu et al. 2019).

\section{Astragaloside IV}

Astragaloside IV (ASV) is one of the most active compounds isolated from root of an inedible herb Astragalus membranaceus. This herb is widely used in traditional Chinese medicine to treat several fibrotic diseases including systemic sclerosis and liver fibrosis (Zhang et al. 2020), however, it might be also effective in silicosis and other types of lung fibrosis. For instance, Li et al. (2019) found that intraperitoneally injected ASV once a day to rats with silicosis can reduce the expression of markers of fibrosis, i.e. $\alpha$-SMA as a marker of activation of myofibroblasts, and collagen I and collagen III as markers of abundant production of extracellular matrix. The therapeutic action of ASV may be partially mediated by suppression of TGF- $\beta 1 / \mathrm{Smad} 3$ signaling pathway as a continuous phosphorylation of Smad3 is a major factor in causing fibrosis (Li et al. 2021a). Similarly in bleomycin-induced lung fibrosis in rats, ASV downregulated the levels of HMGB1 in serum and lung tissue and inhibited the bleomycin-upregulated expression of $\alpha$-SMA and other markers of synthesis of lung extracellular matrix (collagen III, laminin, hyaluronic acid, hydroxyproline) (Li et al. 2017b).

ASV treatment may also prevent the fibrosis downregulating TGF- $\beta 1 / \mathrm{PI} 3 \mathrm{~K} / \mathrm{Akt}$ pathway as it was demonstrated in a rat model of bleomycin-induced pulmonary fibrosis (Qian et al. 2018). Presumably due to suppression of TGF- $\beta 1 / \mathrm{PI} 3 \mathrm{~K} / \mathrm{Akt}$ pathway, intragastric ASV given daily for 14 days starting at day 15 of induction of fibrosis modulated a TGF- $\beta 1$-dependent epithelial-mesenchymal transition (EMT) (Qian et al. 2018). Potent antioxidant and anti-inflammatory effects of ASV may be also related to inhibition of NF- $\kappa \mathrm{B}$ expression (Zhang and Frei 2015) and agonism with glucocorticoid receptors (Zhang et al. 2020). In bleomycin-induced lung fibrosis model in rats, intraperitoneal ASV given daily for 28 days attenuated markers of oxidative stress and inflammation what was confirmed by decreased counts of inflammatory cells and concentrations of TNF $\alpha$, IL- $1 \beta$ and IL-6 in BALF (Yu et al. 2016). 
In a recent in vitro study, ASV prevented invasion and EMT of TGF- $\beta$-induced cells, delaying a progress of pulmonary fibrosis. In addition, ASV downregulated expression of NLRP3 inflammasome (Hou et al. 2021). This finding is in accordance with other studies where ASV prevented an activation of NLRP3 inflammasome (Wan et al. 2018, Qu et al. 2019).

\section{Dioscin}

Dioscin is a widely occurring steroidal saponin present in a variety of vegetables and herbs, particularly in the species of Dioscoreaceae, Liliacae and Solanacae (Yang et al. 2019). Because of potent anti-inflammatory, immunoregulation, hypolipidemic, anti-viral, anti-fungal, and anti-allergic effects, dioscin has wide medicinal and pharmaceutical applications in various disorders including tissue fibrosis (Tao et al. 2018). Likely via inhibiting the TLR4/MyD88/NF- $\mathrm{B}$ signaling pathway, dioscin decreased pro-inflammatory cytokines $\mathrm{TNF} \alpha$, IL-1 $\beta$ and IL-6, declined pro-fibrotic factors TGF- $\beta 1$, $\alpha$-SMA, collagen I and fibronectin, inhibited EMT, and thereby attenuated a peritoneal fibrosis (Shao et al. 2019) or alleviated alcoholic liver fibrosis (Liu et al. 2015b). However, promising results have been also demonstrated in the pulmonary silicosis. In murine models of silicosis, daily oral administration of dioscin exerted antiinflammatory and anti-fibrotic effects through alleviating an apoptosis of alveolar macrophages and promoting an autophagy, a special protective form of the cell elimination ( $\mathrm{Du}$ et al. 2019). Dioscin-stimulated autophagy mitigated a silica-induced release of mitochondrial ROS, mitochondrial dysfunction, and apoptosis of alveolar macrophages what resulted in reduced generation of pro-inflammatory factors, and decreased inflammatory lung infiltration and collagen deposition (Du et al. 2019).

Oral administration of dioscin to mice with silicosis mitigated a recruitment of fibrocytes, a direct source of fibroblasts, prevented a fibroblast activation, and inhibited TGF- $\beta /$ Smad 3 signaling, leading together to decreased collagen deposition and delayed fibrosis (Li et al. 2017a). In addition, dioscin protected the epithelial cells from silica-induced injury, and reduced macrophage and lymphocyte lung infiltration and secretion (Li et al. 2017a).

As recently published, enhancing alveolar macrophage autophagy and mitophagy may protect the lung not only from silica-induced injury (Tan et al. 2021) but may be valuable also in other forms of the lung fibrosis (Zhao et al. 2020).

\section{Oleanolic acid}

Oleanolic acid (OA) is a plant-derived pentacyclic terpenoid which exists naturally in vegetable oil, food and certain medicinal herbs either as a free acid or as an aglycone of triterpenoid saponins (Pollier and Goossens 2012). OA exhibits numerous pharmacological properties, including hepatoprotective, anti-oxidative, anti-inflammatory and anti-cancer effects (Pollier and Goossens 2012). Anti-oxidant and hepatoprotective effects are mediated via activation of PI3K/Akt, JNK, and ERK pathways leading to an increase in nuclear accumulation of Nrf2 (Liu et al. 2008, Wang et al. 2010). Anti-inflammatory and anti-cancer effects are likely mediated by targeting NF-кB pathway (Laszczyk 2009). Thus, OA and its derivatives possess a wide range of potential applications in disorders associated with inflammation and oxidative stress, including renal and liver fibrosis (Pollier and Goossens 2012, Chung et al. 2014) and lung silicosis (Peng et al. 2017).

Intragastric daily administration of $\mathrm{OA}$ to silicotic rats significantly attenuated an extent of silicainduced fibrosis including content of collagen types I and III and reduced oxidative stress what was expressed by a decrease in MDA content and increased activities of anti-oxidant systems (superoxide dismutase and glutathione peroxidase) in the lung. Furthermore, OA decreased the levels of TNF $\alpha$ and TGF- $\beta 1$. These results suggest that the protective effects of OA may be related to both the anti-oxidant activity and the ability to decrease the expression of cytokines and to suppress a synthesis of collagen by modulating the Akt/NF- $\mathrm{kB}$ pathway (Peng et al. 2017).

\section{Hesperetin}

Hesperetin (HSP) is a natural flavonoid present e.g. in citrus fruits that exhibits wide anti-inflammatory, anti-oxidative, anti-bacterial, and anti-cancer effects (Iranshahi et al. 2015, Parhiz et al. 2015). The antiinflammatory action of HSP is likely mediated via increasing the expression of peroxisome proliferatoractivated receptor (PPAR) $\gamma$ and inhibiting the activation of NF- $\kappa$ B pathway (Ma et al. 2015). In an in vitro study, pretreatment of fibroblasts with HSP protected the cells from peroxynitrite-mediated cytotoxicity by intracellular scavenging of ROS and peroxynitrite and modulation of ERK signaling (Hirata et al. 2005, Pollard et al. 2006). Reduction of oxidative stress by HSP is partially 
attributable to stimulation of anti-oxidant systems, as well (Choi et al. 2008).

In rats exposed to silica, HSP reduced an extent of alveolitis and pulmonary fibrosis, declined levels of MDA, increased activity of anti-oxidant enzymes and total antioxidant capacity, inhibited the synthesis and secretion of TGF- $\beta 1$, decreased levels of pro-inflammatory cytokines IL- $1 \beta$, IL-4, and TNF $\alpha$, and elevated levels of anti-inflammatory factors IFN- $\gamma$ and IL-10 (Li et al. 2021b).

\section{Emodin}

Emodin may be extracted from several plants, including Reynoutria japonica Houtt, and Rheum officinale Baill. Emodin has been used in traditional medicines in Eastern and Southern Asia because of antiinflammatory, anti-cancer and anti-fibrotic effects (Cui et al. 2020). Anti-inflammatory effects of emodin were shown in animal models of ovalbumin-induced airway inflammation and hyperreactivity (Wang et al. 2015) and in models of lipopolysaccharide-induced lung, liver and systemic inflammation (Xiao et al. 2014, Jia et al. 2014). The mentioned effects may be mediated by inactivation

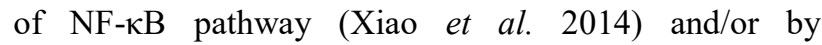
attenuation of activation of NLRP3 inflammasome (Han et al. 2015).

Potent anti-fibrotic effects of emodin were demonstrated in rats with pancreatic fibrosis where emodin suppressed expressions of TGF- $\beta 1$ and collagen and decreased serum levels of hyaluronic acid and laminin, markers of fibrosis (Wang et al. 2007). Similarly in rats with liver fibrosis, emodin suppressed TGF- $\beta 1$ signaling and EMT (Liu et al. 2018). Very promising results for emodin were also found in animal models of bleomycin-induced lung fibrosis (Chen et al. 2009, Guan et al. 2016). In bleomycin-instilled mice, emodin reduced biochemical markers (hydroxyproline content and myeloperoxidase activity) and histopathological markers of lung fibrosis, and decreased TGF- $\beta$, IL-4, and IL-13 in BALF. In addition, emodin decreased fibroblast proliferation and collagen production in a cell culture in adose-dependent manner (Chen et al. 2009). In more recent study, emodin enhanced pulmonary function and improved survival of bleomycin-injured animals, reduced TNF $\alpha$, IL-6, TGF- $\beta 1$ and heat shock protein, alleviated lung edema, decreased collagen deposition and expression of $\alpha$-SMA, suppressed lung infiltration of myofibroblasts, macrophages, and lymphocytes and inhibited TGF- $\beta 1$-induced $\operatorname{Smad} 2 / 3$ and STAT3 activation (Guan et al. 2016).

Emodin was beneficial in animal models of lung silicosis, as well. In a murine model of silica-induced lung fibrosis, emodin improved pulmonary function and reduced deposition of collagen I and $\alpha$-SMA in the lung. The anti-fibrotic effects of emodin were given into relation with emodin-induced increase of sirtuin (Sirt)1 which downregulates TGF- $\beta 1 / \mathrm{Smad}$ fibrotic signaling (Yang et al. 2016). In silica-exposed mice, emodin reduced the degree of alveolitis and fibrosis in the lung, inhibited a phosphorylation of $\operatorname{Smad} 3$ and $N F-\kappa B$ and reduced the levels of TGF- $\beta 1, \alpha$-SMA, collagen-I, TNF $\alpha$ and IL- $1 \beta$ in the lung tissue. In addition, emodin inhibited apoptosis by downregulating the pro-apoptotic protein Bax and upregulating the anti-apoptotic protein Bcl-2. Furthermore, emodin reduced the expressions of markers of fibrosis, apoptosis and inflammation in in vitro cultured human macrophages and alveolar epithelial cells (Pang et al. 2021). The above-mentioned results indicate that emodin can regulate the inflammatory response, EMT and fibrotic process at multiple levels inhibiting the TGF- $\beta 1 /$ Smad3 signaling pathway and the NF- $\kappa B$ signaling pathway.

\section{Conclusions}

Because of complicated pathophysiology, the treatment of pulmonary silicosis is extremely difficult. However, recent studies performed on the experimental models of silicosis have shown that there are several therapeutic approaches which might be of benefit. Among them, positive effects have been found for plantbased compounds which may influence various signaling pathways participating in the development of silicainduced lung fibrosis. With respect to favorable results of herbal medicines in the experimental models of silicainduced lung injury, positive and eventual adverse effects of these treatments should be studied in clinical trials in future to objectively verify a therapeutic potential of these substances.

\section{Conflict of Interest}

There is no conflict of interest.

\section{Acknowledgements}

The work was supported by projects VEGA 1/0356/18 and APVV-15-0075. 


\section{References}

ABDELAZIZ RR, ELKASHEF WF, SAID E: Tadalafil reduces airway hyperactivity and protects against lung and respiratory airways dysfunction in a rat model of silicosis. Int Immunopharmacol 40: 530-541, 2016. https://doi.org/10.1016/j.intimp.2016.10.007

ADAMCAKOVA J, MOKRA D: New insights into pathomechanisms and treatment possibilities for lung silicosis. Int J Mol Sci 22: 4162, 2021. https://doi.org/10.3390/ijms22084162

ALAM W, KHAN H, SHAH MA, CAULI O, SASO L: Kaempferol as a dietary anti-inflammatory agent: Current therapeutic standing. Molecules 25: 4073, 2020. https://doi.org/10.3390/molecules25184073

AMARAL-MACHADO L, OLIVEIRA WN, MOREIRA-OLIVEIRA SS, PEREIRA DT, ALENCAR ÉN, TSAPIS N, EGITO EST: Use of natural products in asthma treatment. Evid Based Complement Alternat Med 2020: 1021258, 2020. https://doi.org/10.1155/2020/1021258

ANG L, SONG E, LEE HW, LEE MS: Herbal medicine for the treatment of Coronavirus Disease 2019 (COVID-19): A systematic review and meta-analysis of randomized controlled trials. J Clin Med 9: 1583, 2020. https://doi.org/10.3390/jcm9051583

BANDEIRA E, OLIVEIRA H, SILVA JD, MENNA-BARRETO RFS, TAKYIA CM, SUK JS, WITWER KW, PAULAITIS ME, HANES J, ROCCO PRM, MORALES MM: Therapeutic effects of adipose-tissue-derived mesenchymal stromal cells and their extracellular vesicles in experimental silicosis. Respir Res 19: 104, 2018. https://doi.org/10.1186/s12931-018-0802-3

BARBARIN V, NIHOUL A, MISSON P, ARRAS M, DELOS M, LECLERCQ I, LISON D, HUAUX F: The role of pro- and anti-inflammatory responses in silica-induced lung fibrosis. Respir Res 6: 112, 2005. https://doi.org/10.1186/1465-9921-6-112

BARNES H, GOH NSL, LEONG TL, HOY R: Silica-associated lung disease: An old-world exposure in modern industries. Respirology 24: 1165-1175, 2019. https://doi.org/10.1111/resp.13695

BERGSBAKEN T, FINK SL, COOKSON BT: Pyroptosis: host cell death and inflammation. Nat Rev Microbiol 7: 99-109, 2009. https://doi.org/10.1038/nrmicro2070

CASELEY EA, POULTER JA, RODRIGUES F; IMMUNOME PROJECT CONSORTIUM FOR AUTOINFLAMMATORY DISORDERS (IMMUNAID), MCDERMOTT MF: Inflammasome inhibition under physiological and pharmacological conditions. Genes Immun 21: 211-223, 2020. https://doi.org/10.1038/s41435020-0104-X

CHEN S, CUI G, PENG C, LAVIN MF, SUN X, ZHANG E, YANG Y, GUAN Y, DU Z, SHAO H: Transplantation of adipose-derived mesenchymal stem cells attenuates pulmonary fibrosis of silicosis via anti-inflammatory and anti-apoptosis effects in rats. Stem Cell Res Ther 9: 110, 2018. https://doi.org/10.1186/s13287-018-0846-9

CHEN XH, SUN RS, HU JM, MO ZY, YANG ZF, JIN GY, GUAN WD, ZHONG NS: Inhibitory effect of emodin on bleomycin-induced pulmonary fibrosis in mice. Clin Exp Pharmacol Physiol 36: 146-153, 2009. https://doi.org/10.1111/j.1440-1681.2008.05048.x

CHOI EJ: Antioxidative effects of hesperetin against 7,12-dimethylbenz(a)anthracene-induced oxidative stress in mice. Life Sci 82: 1059-1064, 2008. https://doi.org/10.1016/j.lfs.2008.03.002

CHOI M, BAN T, RHIM T: Therapeutic use of stem cell transplantation for cell replacement or cytoprotective effect of microvesicle released from mesenchymal stem cell. Mol Cells 37: 133-139, 2014. https://doi.org/10.14348/molcells.2014.2317

CHUNG S, YOON HE, KIM SJ, KIM SJ, KOH ES, HONG YA, PARK CW, CHANG YS, SHIN SJ: Oleanolic acid attenuates renal fibrosis in mice with unilateral ureteral obstruction via facilitating nuclear translocation of Nrf2. Nutr Metab (Lond) 11: 2, 2014. https://doi.org/10.1186/1743-7075-11-2

CUI Y, CHEN LJ, HUANG T, YING JQ, LI J: The pharmacology, toxicology and therapeutic potential of anthraquinone derivative emodin. Chin J Nat Med 18: 425-435, 2020. https://doi.org/10.1016/S1875-5364(20)30050-9

CULLINAN P, REID P: Pneumoconiosis. Prim Care Respir J 22: 249-252, 2013. https://doi.org/10.4104/pcrj.2013.00055

DAS S, KUMAR M, NEGI V, PATTNAIK B, PRAKASH YS, AGRAWAL A, GHOSH B: MicroRNA-326 regulates profibrotic functions of transforming growth factor- $\beta$ in pulmonary fibrosis. Am J Respir Cell Mol Biol 50: 882-892, 2014. https://doi.org/10.1165/rcmb.2013-01950C 
DOS SANTOS G, KUTUZOV MA, RIDGE KM: The inflammasome in lung diseases. Am J Physiol Lung Cell Mol Physiol 303: L627-L633, 2012. https://doi.org/10.1152/ajplung.00225.2012

DU S, LI C, LU Y, LEI X, ZHANG Y, LI S, LIU F, CHEN Y, WENG D, CHEN J: Dioscin alleviates crystalline silicainduced pulmonary inflammation and fibrosis through promoting alveolar macrophage autophagy. Theranostics 9: 1878-1892, 2019. https://doi.org/10.7150/thno.29682

FEHRHOLZ M, GLASER K, SPEER CP, SEIDENSPINNER S, OTTENSMEIER B, KUNZMANN S: Caffeine modulates glucocorticoid-induced expression of CTGF in lung epithelial cells and fibroblasts. Respir Res 18: 51, 2017. https://doi.org/10.1186/s12931-017-0535-8

FERREIRA TPT, LIMA JGME, FARIAS-FILHO FA, JANNINI DE SÁ YAP, DE ARANTES ACS, GUIMARÃES FV, CARVALHO VF, HOGABOAM C, WALLACE J, MARTINS MA, SILVA PMRE: Intranasal flunisolide suppresses pathological alterations caused by silica particles in the lungs of mice. Front Endocrinol (Lausanne) 11: 388, 2020. https://doi.org/10.3389/fendo.2020.00388

GUAN R, ZHAO X, WANG X, SONG N, GUO Y, YAN X, JIANG L, CHENG W, SHEN L: Emodin alleviates bleomycin-induced pulmonary fibrosis in rats. Toxicol Lett 262: 161-172, 2016. https://doi.org/10.1016/j.toxlet.2016.10.004

HAMILTON RF JR, THAKUR SA, HOLIAN A: Silica binding and toxicity in alveolar macrophages. Free Radic Biol Med 44: 1246-1258, 2008. https://doi.org/10.1016/j.freeradbiomed.2007.12.027

HAN JW, SHIM DW, SHIN WY, HEO KH, KWAK SB, SIM EJ, JEONG JH, KANG TB, LEE KH: Anti-inflammatory effect of emodin via attenuation of NLRP3 inflammasome activation. Int J Mol Sci 16: 8102-8109, 2015. https://doi.org/10.3390/ijms16048102

HARIJITH A, EBENEZER DL, NATARAJAN V: Reactive oxygen species at the crossroads of inflammasome and inflammation. Front Physiol 5: 352, 2014. https://doi.org/10.3389/fphys.2014.00352

HIRATA A, MURAKAMI Y, SHOJI M, KADOMA Y, FUJISAWA S: Kinetics of radical-scavenging activity of hesperetin and hesperidin and their inhibitory activity on COX-2 expression. Anticancer Res 25: 3367-3374, 2005.

HOU Y, ZHEN Y, XUE Q, WANG W: Astragaloside IV attenuates TGF- $\beta$-mediated epithelial-mesenchymal transition of pulmonary fibrosis via suppressing NLRP3 expression in vitro. Pharmazie 76: 97-102, 2021. https://doi.org/10.1691/ph.2021.0933

IRANSHAHI M, REZAEE R, PARHIZ H, ROOHBAKHSH A, SOLTANI F: Protective effects of flavonoids against microbes and toxins: The cases of hesperidin and hesperetin. Life Sci 137: 125-132, 2015. https://doi.org/10.1016/j.lfs.2015.07.014

JIA X, IWANOWYCZ S, WANG J, SAAOUD F, YU F, WANG Y, HU J, CHATTERJEE S, WANG Q, FAN D: Emodin attenuates systemic and liver inflammation in hyperlipidemic mice administrated with lipopolysaccharides. Exp Biol Med (Maywood) 239: 1025-1035, 2014. https://doi.org/10.1177/1535370214530247

JIANG L, WANG J, JU J, DAI J: Salvianolic acid B and sodium tanshinone II A sulfonate prevent pulmonary fibrosis through anti-inflammatory and anti-fibrotic process. Eur J Pharmacol 883: 173352, 2020. https://doi.org/10.1016/j.ejphar.2020.173352

KIM KH, LEE MS: Autophagy--a key player in cellular and body metabolism. Nat Rev Endocrinol 10: 322-337, 2014. https://doi.org/10.1038/nrendo.2014.35

KOLB M, RAGHU G, WELLS AU, BEHR J, RICHELDI L, SCHINZEL B, QUARESMA M, STOWASSER S, MARTINEZ FJ; INSTAGE INVESTIGATORS: Nintedanib plus sildenafil in patients with idiopathic pulmonary fibrosis. N Engl J Med 379: 1722-1731, 2018. https://doi.org/10.1056/NEJMoa1811737

LASZCZYK MN: Pentacyclic triterpenes of the lupane, oleanane and ursane group as tools in cancer therapy. Planta Med 75: 1549-1560, 2009. https://doi.org/10.1055/s-0029-1186102

LEE CM, PARK JW, CHO WK, ZHOU Y, HAN B, YOON PO, CHAE J, ELIAS JA, LEE CG: Modifiers of TGF- $\beta 1$ effector function as novel therapeutic targets of pulmonary fibrosis. Korean J Intern Med 29: 281-290, 2014. https://doi.org/10.3904/kjim.2014.29.3.281

LI C, LU Y, DU S, LI S, ZHANG Y, LIU F, CHEN Y, WENG D, CHEN J: Dioscin exerts protective effects against crystalline silica-induced pulmonary fibrosis in mice. Theranostics 7: 4255-4275, $2017 \mathrm{a}$. https://doi.org/10.7150/thno.20270 
LI LC, XU L, HU Y, CUI WJ, CUI WH, ZHOU WC, KAN LD: Astragaloside IV improves bleomycin-induced pulmonary fibrosis in rats by attenuating extracellular matrix deposition. Front Pharmacol 8: 513, $2017 \mathrm{~b}$. https://doi.org/10.3389/fphar.2017.00513

LI N, FENG F, WU K, ZHANG H, ZHANG W, WANG W: Inhibitory effects of astragaloside IV on silica-induced pulmonary fibrosis via inactivating TGF- $\beta 1 /$ Smad3 signaling. Biomed Pharmacother 119:1093872019, 2019. https://doi.org/10.1016/j.biopha.2019.109387

LI N, WU K, FENG F, WANG L, ZHOU X, WANG W: Astragaloside IV alleviates silica-induced pulmonary fibrosis via inactivation of the TGF- $\beta 1 / \mathrm{Smad} 2 / 3$ signaling pathway. Int $\mathrm{J}$ Mol Med 47: 16, $2021 \mathrm{a}$. https://doi.org/10.3892/ijmm.2021.4849

LI S, SHAO L, FANG J, ZHANG J, CHEN Y, YEO AJ, LAVIN MF, YU G, SHAO H: Hesperetin attenuates silicainduced lung injury by reducing oxidative damage and inflammatory response. Exp Ther Med 21: 297, 2021 b. https://doi.org/10.3892/etm.2021.9728

LI X, AN G, WANG Y, LIANG D, ZHU Z, TIAN L: Targeted migration of bone marrow mesenchymal stem cells inhibits silica-induced pulmonary fibrosis in rats. Stem Cell Res Ther 9: 335, 2018. https://doi.org/10.1186/s13287-018$1083-\mathrm{y}$

LIU F, ZHANG J, QIAN J, WU G, MA Z: Emodin alleviates CCl4-induced liver fibrosis by suppressing epithelialmesenchymal transition and transforming growth factor- $\beta 1$ in rats. Mol Med Rep 18: 3262-3270, 2018. https://doi.org/10.3892/mmr.2018.9324

LIU H, YU H, CAO Z, GU J, PEI L, JIA M, SU M: Kaempferol modulates autophagy and alleviates silica-induced pulmonary fibrosis. DNA Cell Biol 38: 1418-1426, 2019. https://doi.org/10.1089/dna.2019.4941

LIU J, WU Q, LU YF, PI J: New insights into generalized hepatoprotective effects of oleanolic acid: Key roles of metallothionein and Nrf2 induction. Bioch Pharmacol 76: 922-928, 2008. https://doi.org/10.1016/j.bcp.2008.07.021

LIU WW, WANG HX, YU W, BI XY, CHEN JY, CHEN LZ, DING L, HAN DM, GUO ZK, LEI YX. Treatment of silicosis with hepatocyte growth factor-modified autologous bone marrow stromal cells: a non-randomized study with follow-up. Genet Mol Res 14: 10672-10681, 2015a. https://doi.org/10.4238/2015.September.9.7

LIU M, XU Y, HAN X, YIN L, XU L, QI Y, ZHAO Y, LIU K, PENG J: Dioscin alleviates alcoholic liver fibrosis by

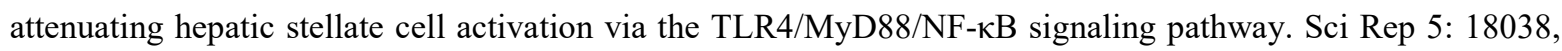
2015b. https://doi.org/10.1038/srep18038

LOPES-PACHECO M, BANDEIRA E, MORALES MM: Cell-based therapy for silicosis. Stem Cells Int 2016: 5091838, 2016. https://doi.org/10.1155/2016/5091838

MA H, FENG X, DING S: Hesperetin attenuates ventilator-induced acute lung injury through inhibition of NF- $\mathrm{BB}-$ mediated inflammation. Eur J Pharmacol 769: 333-341, 2015. https://doi.org/10.1016/j.ejphar.2015.11.038

MA S, WANG X, WANG Y, ZUO X: Sodium tanshinone IIA sulfonate improves hemodynamic parameters, cytokine release, and multi-organ damage in endotoxemia rabbits. Med Sci Monit 24: 2975-2982, 2018. https://doi.org/10.12659/MSM.909996

ØVREVIK J, REFSNES M, LÅG M, HOLME JA, SCHWARZE PE: Activation of proinflammatory responses in cells of the airway mucosa by particulate matter: Oxidant- and non-oxidant-mediated triggering mechanisms. Biomolecules 5: 1399-1440, 2015. https://doi.org/10.3390/biom5031399

PALIKARAS K, LIONAKI E, TAVERNARAKIS N: Mechanisms of mitophagy in cellular homeostasis, physiology and pathology. Nat Cell Biol 20: 1013-1022, 2018. https://doi.org/10.1038/s41556-018-0176-2

PANG X, SHAO L, NIE X, YAN H, LI C, YEO AJ, LAVIN MF, XIA Q, SHAO H, YU G, JIA Q, PENG C: Emodin attenuates silica-induced lung injury by inhibition of inflammation, apoptosis and epithelial-mesenchymal transition. Int Immunopharmacol 91: 107277, 2021. https://doi.org/10.1016/j.intimp.2020.107277

PARDALI E, SANCHEZ-DUFFHUES G, GOMEZ-PUERTO MC, TEN DIJKE P: TGF- $\beta$-induced endothelialmesenchymal transition in fibrotic diseases. Int J Mol Sci 18: 2157, 2017. https://doi.org/10.3390/ijms18102157

PARHIZ H, ROOHBAKHSH A, SOLTANI F, REZAEE R, IRANSHAHI M: Antioxidant and anti-inflammatory properties of the citrus flavonoids hesperidin and hesperetin: an updated review of their molecular mechanisms and experimental models. Phytother Res 29: 323-331, 2015. https://doi.org/10.1002/ptr.5256 
PENG H, WANG R, DENG H, WANG Y, TANG J, CAO F, WANG J: Protective effects of oleanolic acid on oxidative stress and the expression of cytokines and collagen by the AKT/NF $\kappa \mathrm{B}$ pathway in silicotic rats. Mol Med Rep 15: 3121-3128, 2017. https://doi.org/10.3892/mmr.2017.6402

PHINNEY DG, Di GIUSEPPE M, NJAH J, SALA E, SHIVA S, ST CROIX CM, STOLZ DB, WATKINS SC, DI YP, LEIKAUF GD, KOLLS J, RICHES DW, DEIULIIS G, KAMINSKI N, BOREGOWDA SV, MCKENNA DH, ORTIZ LA: Mesenchymal stem cells use extracellular vesicles to outsource mitophagy and shuttle microRNAs. Nat Commun 6: 8472, 2015. https://doi.org/10.1038/ncomms9472

POLLARD SE, WHITEMAN M, SPENCER JP: Modulation of peroxynitrite-induced fibroblast injury by hesperetin: A role for intracellular scavenging and modulation of ERK signalling. Biochem Biophys Res Commun 347: 916-923, 2006. https://doi.org/10.1016/j.bbrc.2006.06.153

POLLIER J, GOOSSENS A: Oleanolic acid. Phytochemistry 77: $10-15, \quad 2012$. https://doi.org/10.1016/j.phytochem.2011.12.022

QI Y, ZHAO A, YANG P, JIN L, HAO C: miR-34a-5p Attenuates EMT through targeting SMAD4 in silica-induced pulmonary fibrosis. J Cell Mol Med 24: 12219-12224, 2020. https://doi.org/10.1111/jcmm.15853

QIAN W, CAI X, QIAN Q, ZHANG W, WANG D: Astragaloside IV modulates TGF- $\beta 1$-dependent epithelialmesenchymal transition in bleomycin-induced pulmonary fibrosis. J Cell Mol Med 22: 4354-4365, 2018. https://doi.org/10.1111/jcmm.13725

QU X, GAO H, ZHAI J, SUN J, TAO L, ZHANG Y, SONG Y, HU T: Astragaloside IV enhances cisplatin chemosensitivity in hepatocellular carcinoma by suppressing MRP2. Eur J Pharm Sci 148: 105325, 2020. https://doi.org/10.1016/j.ejps.2020.105325

RABOLLI V, LO RE S, UWAMBAYINEMA F, YAKOUB Y, LISON D, HUAUX F: Lung fibrosis induced by crystalline silica particles is uncoupled from lung inflammation in NMRI mice. Toxicol Lett 203: 127-134, 2011. https://doi.org/10.1016/j.toxlet.2011.03.009

SANTANA FP, PINHEIRO NM, MERNAK MI, RIGHETTI RF, MARTINS MA, LAGO JH, LOPES FD, TIBÉRIO IF, PRADO CM: Evidences of herbal medicine-derived natural products effects in inflammatory lung diseases. Mediators Inflamm 2016: 2348968, 2016. https://doi.org/10.1155/2016/2348968

SAYAN M, MOSSMAN BT: The NLRP3 inflammasome in pathogenic particle and fibre-associated lung inflammation and diseases. Part Fibre Toxicol 13: 51, 2016. https://doi.org/10.1186/s12989-016-0162-4

SHAO Q, JIANG C, XIA Y, ZHAO M, ZHANG Q, JIN B, LIU J: Dioscin ameliorates peritoneal fibrosis by inhibiting epithelial-to-mesenchymal transition of human peritoneal mesothelial cells via the TLR4/MyD88/NF- $\mathrm{B}$ signaling pathway. Int J Clin Exp Pathol 12: 867-875, 2019.

SHERGIS JL, WU L, ZHANG AL, GUO X, LU C, XUE CC: Herbal medicine for adults with asthma: A systematic review. J Asthma 53: 650-659, 2016. https://doi.org/10.3109/02770903.2015.1101473

SISSON TH, CHRISTENSEN PJ, MURAKI Y, DILS AJ, CHIBUCOS L, SUBBOTINA N, TOHYAMA K, HOROWITZ JC, MATSUO T, BAILIE M, NIKAM S, HAZAMA M: Phosphodiesterase 4 inhibition reduces lung fibrosis following targeted type II alveolar epithelial cell injury. Physiol Rep 6: e13753, 2018. https://doi.org/10.14814/phy2.13753

SONG L, WENG D, DAI W, TANG W, CHEN S, LI C, CHEN Y, LIU F, CHEN J: Th17 can regulate silica-induced lung inflammation through an IL-1beta-dependent mechanism. J Cell Mol Med 18: 1773-1784, 2014. https://doi.org/10.1111/jcmm.12341

STAFFORD M, CAPPA A, WEYANT M, LARA A, ELLIS J JR, WEITZEL NS, PUSKAS F: Treatment of acute silicoproteinosis by whole-lung lavage. Semin Cardiothorac Vasc Anesth 17: 152-159, 2013. https://doi.org/10.1177/1089253213486524

SUGIMOTO N, SUZUKAWA M, NAGASE H, KOIZUMI Y, RO S, KOBAYASHI K, YOSHIHARA H, KOJIMA Y, KAMIYAMA-HARA A, HEBISAWA A, OHTA K: IL-9 blockade suppresses silica-induced lung inflammation and fibrosis in mice. Am J Respir Cell Mol Biol 60: 232-243, 2019. https://doi.org/10.1165/rcmb.2017-0287OC

TAN S, CHEN S: Macrophage autophagy and silicosis: Current perspective and latest insights. Int J Mol Sci 22: 453, 2021. https://doi.org/10.3390/ijms22010453

TAO X, YIN L, XU L, PENG J: Dioscin: A diverse acting natural compound with therapeutic potential in metabolic diseases, cancer, inflammation and infections. Pharmacol Res 137: 259-269, 2018. https://doi.org/10.1016/j.phrs.2018.09.022 
TRENTIN PG, FERREIRA TP, ARANTES AC, CIAMBARELLA BT, CORDEIRO RS, FLOWER RJ, PERRETTI M, MARTINS MA, SILVA PM: Annexin A1 mimetic peptide controls the inflammatory and fibrotic effects of silica particles in mice. Br J Pharmacol 172: 3058-3071, 2015. https://doi.org/10.1111/bph.13109

TSCHOPP J, SCHRODER K: NLRP3 inflammasome activation: The convergence of multiple signalling pathways on ROS production? Nat Rev Immunol 10: 210-215, 2010. https://doi.org/10.1038/nri2725

WAGNER L, CRAMER H, KLOSE P, LAUCHE R, GASS F, DOBOS G, LANGHORST J: Herbal medicine for cough: A systematic review and meta-analysis. Forsch Komplementmed 22: 359-368, 2015. https://doi.org/10.1159/000442111

WAN Y, XU L, WANG Y, TUERDI N, YE M, QI R: Preventive effects of astragaloside IV and its active sapogenin cycloastragenol on cardiac fibrosis of mice by inhibiting the NLRP3 inflammasome. Eur J Pharmacol 833: 545-554, 2018. https://doi.org/10.1016/j.ejphar.2018.06.016

WANG CH, GAO ZQ, YE B, CAI JT, XIE CG, QIAN KD, DU Q: Effect of emodin on pancreatic fibrosis in rats. World J Gastroenterol 13: 378-382, 2007. https://doi.org/10.3748/wjg.v13.i3.378

WANG CM, HE QZ, ZHANG RX: Effects of tanshionone to bleomycin induced pulmonary fibrosis of rats on histological changes and production of lipid peroxides and hydroxyproline. (Article in Chinese) Zhonghua Jie He He Hu Xi Za Zhi 17: 308-310, 1994.

WANG T, ZHONG XG, LI YH, JIA X, ZHANG SJ, GAO YS, LIU M, WU RH: Protective effect of emodin against airway inflammation in the ovalbumin-induced mouse model. Chin J Integr Med 21: 431-437, 2015. https://doi.org/10.1007/s11655-014-1898-z

WANG X, YE XL, LIU R, CHEN HL, BAI H, LIANG X, ZHANG XD, WANG Z, LI WL, HAI CX: Antioxidant activities of oleanolic acid in vitro: possible role of Nrf2 and MAP kinases. Chem Biol Interact 184: 328-337, 2010. https://doi.org/10.1016/j.cbi.2010.01.034

WU Y, TIAN YJ, LE ML, ZHANG SR, ZHANG C, HUANG MX, JIANG MY, ZHANG B, LUO HB: Discovery of novel selective and orally bioavailable phosphodiesterase-1 inhibitors for the efficient treatment of idiopathic pulmonary fibrosis. J Med Chem 63: 7867-7879, 2020. https://doi.org/10.1021/acs.jmedchem.0c00711

XIAO M, ZHU T, ZHANG W, WANG T, SHEN YC, WAN QF, WEN FQ: Emodin ameliorates LPS-induced acute lung injury, involving the inactivation of NF-kappaB in mice. Int J Mol Sci 15: 19355-19368, 2014. https://doi.org/10.3390/ijms151119355

XIE XY, ZHANG B, LI JH, FAN QX, ZHANG Y, MU DG, LI WP, XU M, ZHAO PT, JIN FG, LI ZC: Sodium tanshinone iia sulfonate attenuates seawater aspiration-induced acute pulmonary edema by up-regulating $\mathrm{Na}(+), \mathrm{K}(+)$-ATPase activity. Exp Lung Res 37: 482-491, 2011. https://doi.org/10.3109/01902148.2011.594144

XU T, YAN W, WU Q, XU Q, YUAN J, LI Y, LI P, PAN H, NI C: MiR-326 inhibits inflammation and promotes autophagy in silica-induced pulmonary fibrosis through targeting TNFSF14 and PTBP1. Chem Res Toxicol 32: 2192-2203, 2019. https://doi.org/10.1021/acs.chemrestox.9b00194

YANG L, REN S, XU F, MA Z, LIU X, WANG L: Recent advances in the pharmacological activities of dioscin. Biomed Res Int 2019: 5763602, 2019. https://doi.org/10.1155/2019/5763602

YANG T, WANG J, PANG Y, DANG X, REN H, LIU Y, CHEN M, SHANG D: Emodin suppresses silica-induced lung fibrosis by promoting Sirt1 signaling via direct contact. Mol Med Rep 14: 4643-4649, 2016. https://doi.org/10.3892/mmr.2016.5838

YANG CC, YANG CM: Chinese herbs and repurposing old drugs as therapeutic agents in the regulation of oxidative stress and inflammation in pulmonary diseases. J Inflamm Res 14: 657-687, 2021. https://doi.org/10.2147/JIR.S293135

YU WN, SUN LF, YANG H: Inhibitory effects of astragaloside IV on bleomycin-induced pulmonary fibrosis in rats via attenuation of oxidative stress and inflammation. Inflammation 39: 1835-1841, 2016. https://doi.org/10.1007/s10753-016-0420-5

ZAHID A, LI B, KOMBE AJK, JIN T, TAO J: Pharmacological inhibitors of the NLRP3 inflammasome. Front Immunol 10: 2538, 2019. https://doi.org/10.3389/fimmu.2019.02538

ZHANG T, LIANG Y, ZHANG J: Natural and synthetic compounds as dissociated agonists of glucocorticoid receptor. Pharmacol Res 156: 104802, 2020. https://doi.org/10.1016/j.phrs.2020.104802 
ZHANG WJ, FREI B: Astragaloside IV inhibits NF-kappa B activation and inflammatory gene expression in LPS-treated mice. Mediators Inflamm 2015: 274314, 2015. https://doi.org/10.1155/2015/274314

ZHANG YM, ZHANG HT, WANG CY, WANG W, WU J, WANG C: Long-term therapeutic effects of whole lung lavage in the management of silicosis. (Article in Chinese) Zhonghua Lao Dong Wei Sheng Zhi Ye Bing Za Zhi 30: 690-693, 2012.

ZHAO H, WANG Y, QIU T, LIU W, YAO P: Autophagy, an important therapeutic target for pulmonary fibrosis diseases. Clin Chim Acta 502: 139-147, 2020. https://doi.org/10.1016/j.cca.2019.12.016

ZHOU ZY, ZHAO WR, ZHANG J, CHEN XL, TANG JT: Sodium tanshinone IIA sulfonate: A review of pharmacological activity and pharmacokinetics. Biomed Pharmacother 118: 109362, 2019. https://doi.org/10.1016/j.biopha.2019.109362

ZHU Z, LI Q, XU C, ZHAO J, LI S, WANG Y, TIAN L: Sodium tanshinone IIA sulfonate attenuates silica-induced pulmonary fibrosis in rats via activation of the Nrf2 and thioredoxin system. Environ Toxicol Pharmacol 80: 103461, 2020. https://doi.org/10.1016/j.etap.2020.103461 